\title{
Removal of lindane and Escherichia coli (E.coli) from rainwater using photocatalytic and adsorption treatment processes
}

\author{
Omar K.F.M. ${ }^{1}$, Aziz N.A.A. ${ }^{1}$, Palaniandy P. ${ }^{1,}{ }^{*}$ and Abu Amr S.S. ${ }^{2}$ \\ ${ }^{1}$ School of Civil Engineering, Engineering Campus, Universiti Sains Malaysia, 14300 Nibong Tebal, Penang, Malaysia \\ ${ }^{2}$ Environmental Engineering Technology, Malaysian Institute of Chemical and Bioengineering Technology, Universiti Kuala Lumpur \\ (UniKL, MICET) 78000 Melaka, Malaysia
}

Received: 28/06/2016, Accepted: 11/10/2016, Available online: 07/03/2017

*to whom all correspondence should be addressed:

e-mail: cepuganeshwary@usm.my

\begin{abstract}
Low concentrations of contaminants in rainwater is the primary benefit of transforming it as an alternative source of drinking water. However, treatment is necessary as rainwater collects contaminants that are persistent in the environment such as lindane and E.coli. The combination of photocatalysis and adsorption processes was chosen as the treatment method in this study. From the results obtained, photocatalysis treatment process was able to degrade lindane in synthetic rainwater under different experimental conditions such as $\mathrm{pH}$, titanium dioxide $\left(\mathrm{TiO}_{2}\right)$ dosage, and initial concentration. The photodegradation process of lindane followed pseudo kinetic first order. In adsorption process, the adsorbents used in the process are limestone and laterite soil. The performance of these adsorbents are determined by carrying out an equilibrium batch study. The experimental works show that limestone and laterite soil able to remove E.coli at $99 \%$. The optimum dosage of limestone and laterite soil to remove E.coli from synthetic rainwater is $6 \mathrm{~g}$ and $2 \mathrm{~g}$, respectively. The results were then analysed by developing Langmuir and Freundlich isotherm model. Overall, the processes of photocatalysis and adsorption showed a good performance in removing lindane and E.coli from the synthetic rainwater respectively.
\end{abstract}

Keywords: synthetic rainwater, $\mathrm{pH}$, titanium dioxide, photodegradation, adsorbents, limestone, laterite soil

\section{Introduction}

In order to provide an alternative solution to the water scarcity problem, rainwater can be collected to serve our water supply system. Generally, harvested rainwater provides a good quality in terms of physicochemical properties (Gikas and Tsihrintzis, 2012). The low concentrations of contaminants in the harvested rainwater is the primary advantage to convert it as an alternative source of drinking water. However, the presence of micropollutants such as organochlorine pesticides (OCPs) and Escherichia coli (E. coli) in the harvested rainwater may affect the human health (Ismail et al. 2013; Wilbers, Sebesvari et al., 2013). OCPs are the persistent organic pollutants (POPs) urgently needed to be eliminated because of their high solubility in greases, which involves an accumulation in fat tissues of the living organisms (Pang, et al. 2009; He and Balasubramanian, 2010). OCPs mostly occur in waters that have been affected by agricultural discharges. Once released into the environment, these OCPs could remain for quite a long time and as the result, these compounds are being collected in the rain droplets as the wet precipitation occurs.

One of the most harmful pesticides that is persistent in the environment is lindane (Devipriya and Yesodharan, 2005). There are several studies that have proven the concentrations of lindane in rainwater (Basheer et al., 2003; He and Balasubramanian, 2009; $\mathrm{He}$ and Balasubramanian, 2010; Mahugija et al., 2015). Naturally, the presence of E.coli in a water body comes from the human and animal fecal waste. The effects of E.coli in water may cause illness and infection to any humans who drink it. Therefore, United States Environment Protection Agency (U.S EPA) has developed a standard limit for E.coli is zero. Hence, further treatment is necessary in order to make the quality of harvested rainwater parallel to the requirements according to the drinking water standard.

Treatment is required to improve the quality of the harvested rainwater. Several potential methods have been studied to treat the harvested rainwater. In 2011, Amin and Han used solar disinfection method with the use of lemon and vinegar as the catalyst. The study showed that solar disinfection was able to remove and inactivate microbiological contaminants from harvested rainwater (Amin and Han, 2011). Other than that, there were also studies of rainwater harvesting treatments by using combination process (Jordan et al., 2008; Naddeo et al., 2013). Jordan and his co-researchers has investigated the use of the combination treatment by using filtration and UV disinfection to remove microbiological contaminants from the harvested rainwater (Jordan et al., 2008). Meanwhile, Naddeo and his co-workers applied the 
combination of filtration, adsorption (using granulated activated carbon), and disinfection (UV light) to enhance the quality of harvested rainwater as drinking water supply. The results showed that the combination process was able to produce clean water in terms of microbiological quality as disinfection process provides a good barrier for pathogens and several major contaminants (Naddeo et al., 2013).

Advanced oxidation processes (AOPs) constitute the best option for the destruction of POPs in the near future (Esplugas et al., 2002). The versality of AOP is enhanced by the fact that they offer different possible ways for hydroxyl radical production thus allowing a better compliance with the specific treatment requirements. One of the most widely used AOPs is photocatalysis. Photocatalysis with $\mathrm{TiO}_{2}$ catalyst has been a promising method to be used in removing the organic and inorganic pollutants in the water treatment as reported in the previous studies (Zaleska et al., 2000; Muneer et al., 2005; Lair et al., 2008; Mahmoodi and Sargolzaei, 2014). The basic principle of semiconductor photocatalysis relies on the formation of an electron-hole pair upon the absorption of a photon with energy equal or bigger than the semiconductor band gap (Robertson et al., 2012). The unlimited supply of sunlight and oxygen, if natural sunlight is to be used, makes photocatalysis better to be used compared to other processes (Malato et al., 2009).

Adsorption process is one of the most commonly applied in rainwater harvesting treatments (Fuping et al., 2012; Gan, et al., 2012; Wang et al., 2013; Yang et al., 2015). Generally, adsorption process can be defined as a mass transfer operation, which a compound can be transferred from liquid phase to solid phase. The substance that is being removed from liquid phase at the interface is described as adsorbate, while adsorbent is the medium which the adsorbate accumulated with in the form of solid, liquid, or gas phase (Tchobanoglous, 2003). Numerous studies have revealed the usage of limestone in various kinds of water treatment (Aziz et al., 2004; Aziz, Adlan et al. 2008; Silva, Cunha et al. 2012; Wang et al., 2013). The presence of calcium carbonate $\left(\mathrm{CaCO}_{3}\right)$ and magnesium carbonate $\left(\mathrm{MgCO}_{3}\right)$ in limestone enable the adsorbent to remove pollutants such as heavy metals from a water body (Aziz et al., 2004; Aziz et al., 2008; Wang et al., 2013). On the other hand, the removal of pollutants by laterite soils was caused by the high content of silica compound. However, these adsorbents are rarely used to study the removal of E.coli.

Therefore, this study was conducted in order to determine the removal efficiency of lindane after being treated with photocatalytic treatment process. Under different experimental conditions: the effects of $\mathrm{pH}$, catalyst loading, and the initial concentration on the degradation percentage of lindane were discussed. The kinetic study on the photodegradation of lindane was also investigated. Besides that, the optimum dosage of limestone and suitable adsorption isotherm model in removing E.coli from synthetic rainwater were examined in this study.

\section{Methodology}

\subsection{Chemical Reagents and Materials}

The chemicals and materials involved in this study were described. The analytical standards of lindane $(\gamma-\mathrm{HCH})$ were purchased from Sigma-Aldrich (Steinhelm, Germany) with a purity of $97.5 \%$. Chloroform used as the organic solvent, also dichloromethane and methanol used as GC eluent were of the analytical residue grade and obtained from Systerm. Titanium dioxide (Degussa P25) used in this work, is a known mixture of $70 \%$ anatase and $30 \%$ rutile, has a $99.5 \%$ purity with mean particle size of $30 \mathrm{~nm}$ and surface area of $50 \mathrm{~m}^{2} / \mathrm{g}$, was supplied from R\&M Marketing, Essex, U.K. Other chemicals were used without further purification. Deionized and doubly distilled water was used throughout this study.

Meanwhile, the source of E. coli in this study was collected froom oxidation pond in Universiti Sains Malaysia in Nibong Tebal, Penang, Malaysia. The materials used in this study are limestone and laterite soil. High quality limestone was sieved to obtain the size of $2.00 \mathrm{~mm}$ mesh. The adsorbent was then washed with distilled water for several times in order to remove dust and other impurities. After that, it was dried in the oven at $105{ }^{\circ} \mathrm{C}$ for 24 hours. The laterite soil were washed by adding $100 \mathrm{~g}$ of laterite soil into $1000 \mathrm{ml}$ of deionized water and were stirred with $250 \mathrm{rpm}$ for 30 minutes. The mixture was then filtered to collect the treated laterite soil and was oven dried at $105{ }^{\circ} \mathrm{C}$ for 24 hours (Lau et al., 2014; Rout et al., 2014). Then, the washed laterite soil was sieved and the sample that retained at $630 \mu \mathrm{m}$ were used for the adsorption process (Maiti et al., 2013).

\subsection{Experimental works}

\subsubsection{Preparation of Synthetic Rainwater}

The synthetic solutions for lindane and E. coli were prepared at low concentration to imitate the condition of real rainwater. Stock solution of lindane was prepared by dissolving the powdered standard of lindane with chloroform and stored at $4{ }^{\circ} \mathrm{C}$ (Huang et al., 2009; Rianawati and Balasubramanian, 2009). Meanwhile, the synthetic rainwater of E.coli was prepared by spiking $1 \mathrm{~mL}$ of wastewater into $1 \mathrm{~L}$ of distilled water. The initial content of E.coli in the synthetic rainwater is $1986 \mathrm{MPN} / 100 \mathrm{~mL}$ after the dilution.

\subsubsection{Photocatalysis and Adsorption Batch Equilibrium Study}

Photocatalytic treatment was carried out by exposure of the synthetic rainwater with titanium dioxide to natural sunlight in different experimental conditions, such as $\mathrm{pH}$, initial concentration of lindane, and dosage of titanium dioxide.

Adsorption batch equilibrium study was formed in determining the optimum adsorbent dosage and adsorption isotherm models. The experiments were carried out with a series of twenty $250 \mathrm{~mL}$ of conical flasks contained of synthetic rainwater for E.coli at $\mathrm{pH} 7$ with adsorbent. The adsorbent dosage for limestone and laterite soil is in a range of $2-20 \mathrm{~g}$. The conical flasks were placed on the orbital shaker at $200 \mathrm{rpm}$ for 60 minutes. 


\subsection{Analytical Method}

The concentration of lindane was obtained by using the liquid-liquid extraction method: $100 \mathrm{ml}$ of the synthetic sample was transferred into a conical flask and mixed with $100 \mathrm{ml}$ of dichloromethane. The mixtures were shaken in a shaking incubator at room temperature for two hours with $120 \mathrm{rpm}$ of shaking speed. After 30 minutes, the two layers were formed. The mixtures were transferred into a separating funnel. From the separating funnel, the lower layer that formed the organic layer was collected and evaporated to dry. After being dried, the extract was mixed with $1 \mathrm{~mL}$ of dichloromethane and ready to be analyzed by GC-MS. The standard solution of lindane was prepared in dichloromethane at concentration of $1 \mathrm{mg} / \mathrm{mL}$ and diluted at concentration of 200000, 20000, 2000, 200, and $20 \mu \mathrm{g} / \mathrm{L}$.

The quantification of lindane was conducted using an Agilent 6890N Series GC System coupled with Agilent 5973 Inert Mass Selective Detector. The column used was Agilent HP-5MS fused capillary column (USA) with description as follows: $30.0 \mathrm{~m} \times 250 \mu \mathrm{m} \times 0.25 \mu \mathrm{m}$. The carrier gas was helium. The inlet temperature was $300{ }^{\circ} \mathrm{C}$. $1 \mu \mathrm{l}$ of the sample was injected into the GC. The temperature program was as follows: initial oven temperature was held at $70{ }^{\circ} \mathrm{C}$ for $2 \mathrm{~min}$, and ramped to $290{ }^{\circ} \mathrm{C}$ at a rate of $15^{\circ} \mathrm{C} / \mathrm{min}$. The mass spectrometer was operated under electron impact (EI), choosing $70 \mathrm{eV}$ as the electron energies, while the ion source temperature was set to $230{ }^{\circ} \mathrm{C}$. Selective ion monitoring (SIM) mode was used for monitoring the analyte. Quantitation ion for lindane is 181 . Lindane was identified by comparing the retention time (chromatographic column) and mass spectra (mass detector) with the standard (full scan mode).

On the other hands, E.Coli content was determined by using IDEXX Colilert Method, which has been approved by U.S EPA and included in Standard Methods of Quality of Water and Wastewater (APHA Standard Method 9221 A-F). This experiment was carried out within 24 hours after preparing the synthetic rainwater in order to maintain the E.coli content in the samples.

\section{Results and Discussion}

\subsection{Photocatalytic Treatment Process}

\subsection{1. $\mathrm{pH}$}

In heterogeneous photocatalytic water system, $\mathrm{pH}$ is one of the most important operational factors that affect the charge on the catalyst particles and the position of the conduction and the valence bands. Due to the nature of $\mathrm{TiO}_{2}$ catalyst used, any variation in the operating $\mathrm{pH}$ is known to affect the isoelectric point or the surface charge of the photocatalyst used (Chong et al., 2010). The point of zero charge (PZC) of the $\mathrm{TiO}_{2}$ (Degussa P25) is widely reported at $\mathrm{pH} 6.25$ (Li et al., 2008). While under acidic conditions, the positive charge on the $\mathrm{TiO}_{2}$ surface increases as the $\mathrm{pH}$ decreases, and above $\mathrm{pH} 6.25$ the negative charge on the surface of the $\mathrm{TiO}_{2}$ increases with increasing $\mathrm{pH}$. Fig. 1 shows the percentage removal of lindane from synthetic rainwater in accordance to different
$\mathrm{pH}$ condition, that is from 3 to 11 . Based on the figure, lindane was highly degraded in this process.

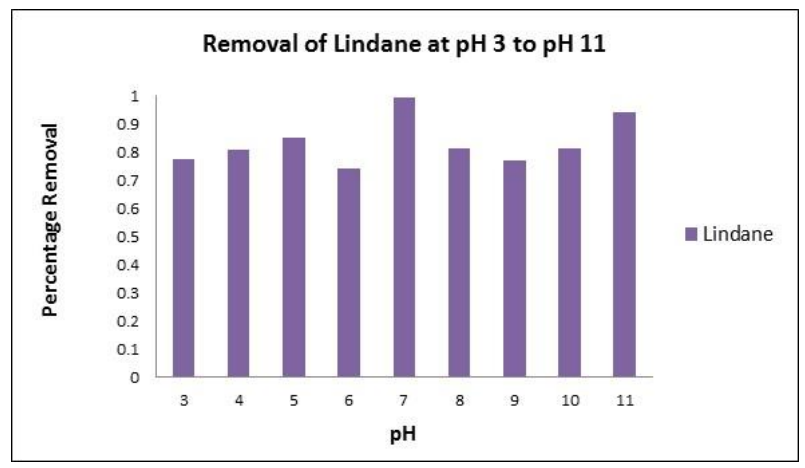

Figure 1. Percentage removal of lindane from synthetic rainwater with $\mathrm{pH} 3$ to 11

\subsection{2. $\mathrm{TiO}_{2}$ Dosage}

Fig. 2 shows the percentage removal of lindane from synthetic rainwater in accordance to different $\mathrm{TiO}_{2}$ dosage, that is from 0.1 to $0.5 \mathrm{~g} / \mathrm{L}$. Based on the figure, lindane obtained maximum degradation when the $\mathrm{TiO}_{2}$ dosage used is $0.2 \mathrm{~g} / \mathrm{L}$, followed by $0.5 \mathrm{~g} / \mathrm{L}$. From this result, it can be concluded that the higher the amount of $\mathrm{TiO}_{2}$ used, the higher the degradation rate. The reason generally for this is that the increase in amount of catalyst increases the number of active sites on the photocatalyst surface, which in turn increase the number of hydroxyl and superoxide radicals (Gaya and Abdullah, 2008).

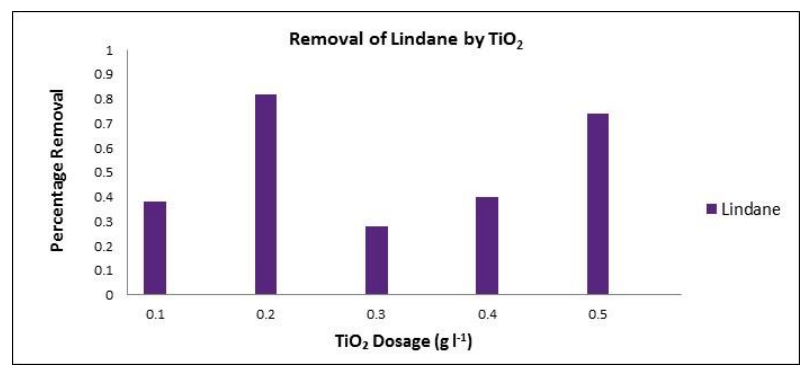

Figure 2. Percentage removal of lindane from synthetic rainwater with $\mathrm{TiO}_{2}$ dosage 0.1 to $0.5 \mathrm{~g} / \mathrm{L}$

However, in the review of $\mathrm{TiO}_{2}$-assisted photocatalytic degradation of azo dyes in aqueous solution reported that in any solar reactor system, the initial rates were found to be directly proportional to catalyst concentration, indicating the heterogeneous regime, until it reached a limit of catalyst concentration at which the rate of photocatalysis will even decrease (Konstantinou and Albanis 2004).

\subsubsection{Initial Concentration}

Fig. 3 shows the percentage removal of lindane from synthetic rainwater in accordance to different initial concentration of pollutant that is from 10 to $100 \mu \mathrm{g} / \mathrm{L}$. Based on the figure, the lowest degradation rate of lindane occurs at 70 and $80 \mu \mathrm{g} / \mathrm{L}$. This shows that the higher the initial concentration of each pollutant, the lower the oxidation rate. Owing to the photonic nature of the 
photocatalysis reaction, excessively high concentration of organic substrate is known to simultaneously sature the $\mathrm{TiO}_{2}$ surface and reduces the efficiency of the light penetration into the solution, leading to photocatalyst deactivation (Muneer et al., 2005). This may be due to the fact that at higher concentrations more substrate molecules could occupy more active sites, thus inhibiting the generation of the oxidants (Yang et al., 2012).

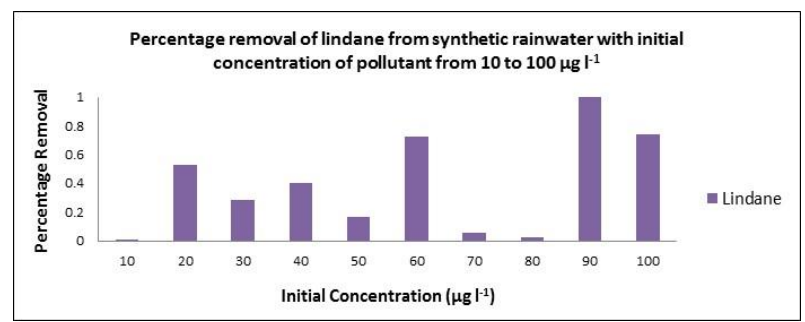

Figure 3. Percentage removal of lindane from synthetic rainwater with initial concentration of pollutant from 10 to $100 \mu \mathrm{g} / \mathrm{L}$

\subsubsection{Kinetics of the Photodegradation Process}

For the kinetic photodegradation processes, pseudo first order equation is normally assumed (Bosco et al., 2006). By using the following equation, the rate constant of the photodegradation process can be calculated:

$$
\ln \frac{\mathrm{C}_{\mathrm{o}}}{\mathrm{C}}=\mathrm{kt}
$$

Where $\mathrm{C}_{0}$ and $\mathrm{C}$ are the pollutant concentrations at times 0 and $t$ respectively, and $\mathrm{k}$ being the rate constant. Fig. 4 shows the photocatalytic degradation of lindane in the synthetic rainwater. Based on the plotted graph, the correlation coefficient of lindane is 0.585 .

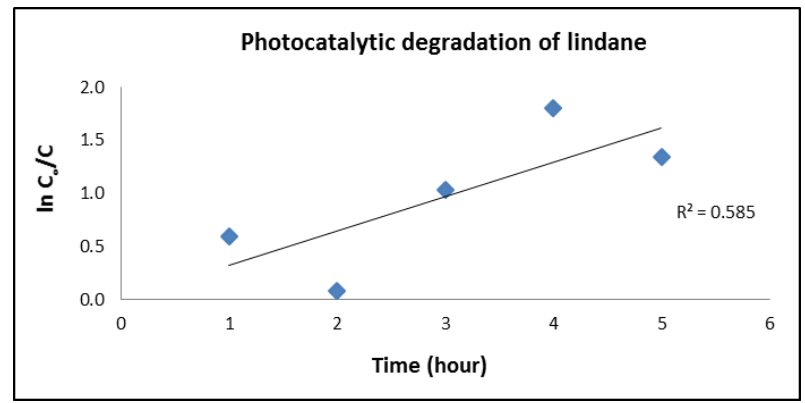

Figure 4. Photocatalytic degradation of lindane

The pseudo rate constants, half life times and the removal percentages of lindane are depicted as in Table 1. From the results below, it is suggested that further studies with wider range of experimental conditions need to be done in order to investigate the behavior and performance of lindane throughout the photocatalytic treatment process.
Table 1. Values of kinetic parameters for photodegradation of lindane.

\begin{tabular}{cccc}
\hline Time (hour) & $\mathbf{k}_{\text {(hour }}{ }^{-1}$ ) & $\begin{array}{c}\mathbf{t} \mathbf{1} \mathbf{2} \\
\text { (hour) }\end{array}$ & $\begin{array}{c}\text { \% Removal } \\
\text { Efficiency }\end{array}$ \\
\hline $\mathbf{1}$ & 0.6 & 1.2 & 45 \\
\hline $\mathbf{2}$ & 0.0 & 17.6 & 8 \\
\hline $\mathbf{3}$ & 0.9 & 0.8 & 94 \\
\hline $\mathbf{4}$ & 0.3 & 2.7 & 64 \\
\hline $\mathbf{5}$ & 0.4 & 1.9 & 84 \\
\hline $\mathbf{6}$ & 0.2 & 3.1 & 74 \\
\hline
\end{tabular}

\subsubsection{Gas chromatography mass spectrometer}

The retention time of lindane was approximately 10.00. Fig. 5 a shows a chromatogram of lindane at concentration of $100 \mu \mathrm{g} / \mathrm{L}$. Fig. 5b shows a chromatogram of lindane after treatment.

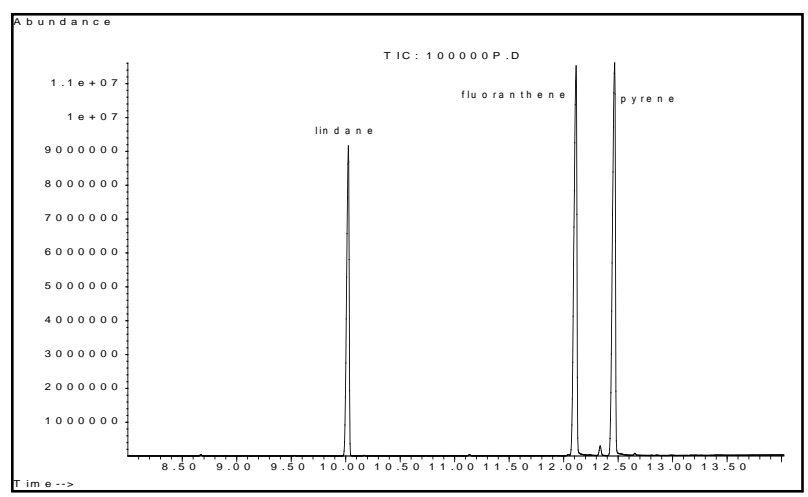

Figure 5a. Chromatogram of lindane at $100 \mu \mathrm{g} / \mathrm{L}$

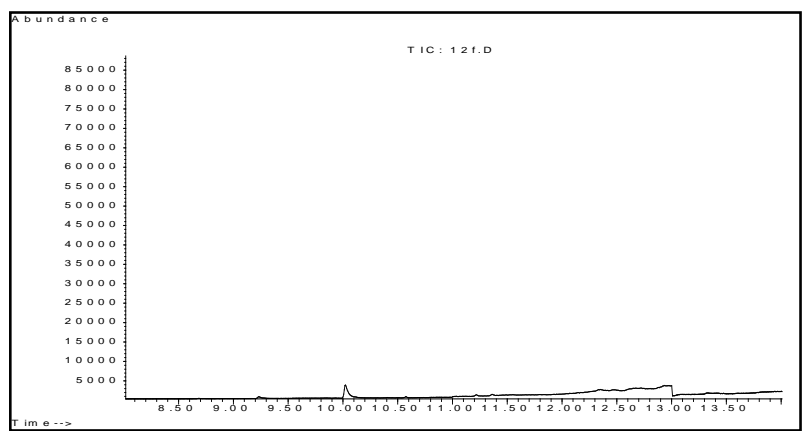

Figure 5b. Chromatogram of lindane after treatment

The calibration curves were established by plotting peak area of analyte. The linear regression equation was calculated by using Microsoft Excel program and is summarized in Table 2.

The LOD is the lowest amount of analyte that can be detected, but not necessarily quantitated as an exact value. LOQ is the lowest amount of analyte that can be quantitatively determined with suitable precision.

Table 2. Linearity of lindane

\begin{tabular}{cccccc}
\hline Analyst & Regression equation & Correlation coefficient & Linearity $(\mu \mathrm{g} / \mathrm{L})$ & LOD* $^{*}\left(\mu \mathrm{g} \mathrm{l^{-1 }}\right)$ & LOQ $^{* *}\left(\mu \mathrm{g} \mathrm{l}{ }^{-1}\right)$ \\
\hline Lindane & $\mathrm{y}=38.40 \mathrm{x}-138360$ & 0.9980 & $20-200000$ & 2 & 20 \\
\hline
\end{tabular}

$*$ LOD $=$ Limit of detection, $* *$ LOQ $=$ Limit of quantification 


\subsection{Adsorption Process}

\subsubsection{Removal of E. coli}

The percentage removals of E.coli were plotted by in Fig. 6 . The figure depicted the removals of E.coli by limestone and laterite soil at the range of $2-20 \mathrm{~g}$. Based on the figure, results indicate the removal of E.coli reached more than $90 \%$ at $2 \mathrm{~g}$ and $6 \mathrm{~g}$ for laterite soil and limestone, respectively.

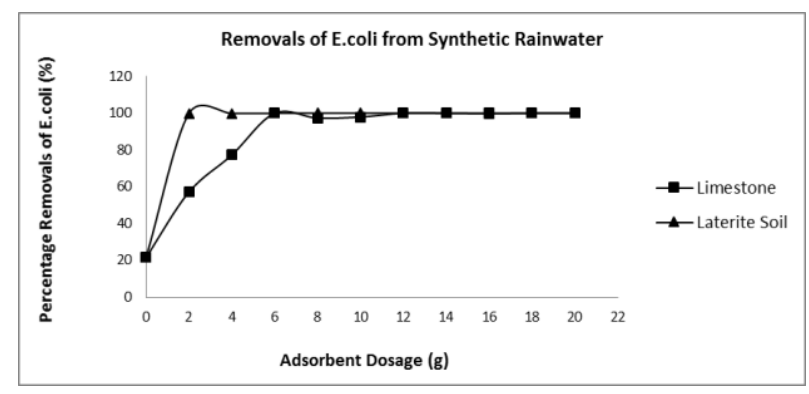

Figure 6. Percentage removal of E.coli from synthetic rainwater

The percentage removal of E.coli for laterite soil was more efficient than limestone due to the smaller particle size of the medium. Smaller particles of adsorbent expose a larger surface area compared to coarse particles. Therefore, it provides more adhesion site of adsorbent (Fontes et al., 1991; Tan et al., 1992). Besides that, another factor that contributed to the removal of E.coli is the presence of divalent cation in the adsorbents. Generally, limestone is highly content of calcium carbonate, while laterite soil contained of iron oxide (Aziz et al., 2008; Maiti et al., 2013). Huysman and Verstraete stated that the presence of divalent cation increased the attachment of bacteria to the surface of adsorbent (Huysman and Verstraete 1993). Therefore, it can be concluded that the presence of $\mathrm{Ca}^{2+}$ and $\mathrm{Fe}^{2+}$ ions in the chemical compound enhanced the attachment of E.coli to the adsorbents.

\subsubsection{Adsorption Isotherm Model}

Adsorption isotherm is a function of the concentration of adsorbate at constant temperature in order to determine the amount of material adsorbed. The adsorbent phase concentration can be computed by Equation (2) below (Tchobanoglous, 2003; Halim et al., 2010; Rout et al., 2014):

$$
q_{e}=\frac{\left(C_{o}-C_{e}\right) V}{m}
$$

Where;

$\mathrm{q}_{\mathrm{e}}=$ adsorbent phase concentration after equilibrium, MPN E.coli adsorbate/g adsorbent

$\mathrm{C}_{0}=$ initial concentration of adsorbate, MPN/100mL

$\mathrm{C}_{\mathrm{e}}=$ final equilibrium concentration of adsorbate after adsorption has occurred, MPN/100mL

$\mathrm{V}=$ volume of liquid in the reactor, $\mathrm{mL}$

$\mathrm{m}=$ mass of adsorbent, $\mathrm{g}$
In this study, the chosen adsorption isotherms were Langmuir isotherm model and Freundlich isotherm model. These isotherms were chosen in order to determine the efficiency of adsorption process.

\subsubsection{Langmuir Isotherm Model}

Langmuir isotherm model assumes a fixed number of sites and only one solute molecule per site of adsorbent and suggest the monolayer adsorption on a homogeneous surface (Tchobanoglous, 2003; Halim et al.; 2010, Rout et al., 2014). The Langmuir isotherm relates with $q_{e}$ (mg of adsorbate adsorbed per gram of adsorbent media) and $C_{e}$ (the equilibrium adsorbate concentration in solution) as shown in Equation 3 (Aziz et al., 2008; Halim et al., 2010; Ismail et al., 2013):

$$
q_{e}=\frac{Q b C_{e}}{\left(1+b C_{e}\right)}
$$

Where;

$\mathrm{Q}=$ maximum adsorption capacity, MPN/g

$\mathrm{b}=$ Langmuir constant, L/mg

The constant in Langmuir isotherm can be determined by plotting graph of $\mathrm{Ce} / \mathrm{q}_{\mathrm{e}}$ against $\mathrm{Ce}$ which can be rewrite as shown in Equation (4):

$$
\frac{\mathrm{C}_{\mathrm{e}}}{\mathrm{q}_{\mathrm{e}}}=\frac{1}{\mathrm{Qb}}+\frac{\mathrm{C}_{\mathrm{e}}}{\mathrm{Q}}
$$

Based on the Langmuir isotherm model equation, a dimensionless constant that indicates the nature of the monolayer adsorption can be determined. It is expressed in terms of equilibrium parameter, $\mathrm{R}_{\mathrm{L}}$ as shown in Equation (5):

$$
\mathrm{R}_{\mathrm{L}}=\frac{1}{1+\left(1+\mathrm{bC}_{\mathrm{o}}\right)}
$$

Where,

$\mathrm{R}_{\mathrm{L}}=$ equilibrium parameter

$\mathrm{b}=$ Langmuir constant $(\mathrm{L} / \mathrm{g})$

$\mathrm{Co}=$ initial concentration of E.coli (MPN/100mL)

The $R_{L}$ value determine the monolayer adsorption nature to be either unfavorable if $R_{L}>1$, linear if $R_{L}=1$, favorable if $0<R_{L}<1$ and irreversible if $R_{L}=0$ (Halim et al., 2010; Rout et al., 2014).

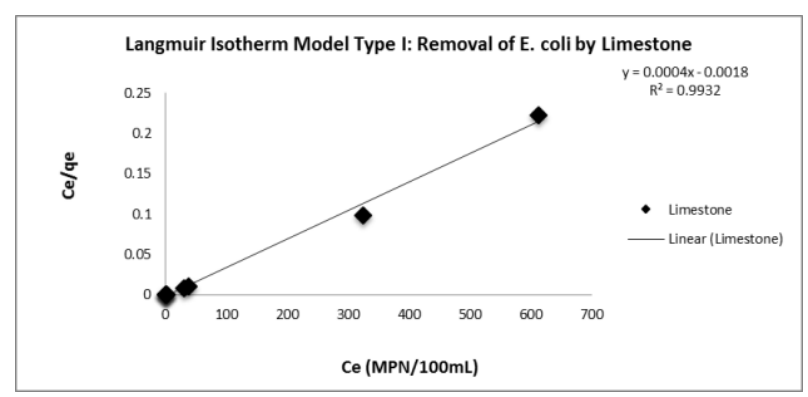

Figure 7. Langmuir Isotherm Model for Removal of E.coli by Limestone 
In this research, the Langmuir isotherm model equation and correlation coefficient, $\mathrm{R}^{2}$ for E.coli uptake from synthetic rainwater to limestone and laterite soil are depicted in Fig. 7 and Fig. 8. Based on the figures, the values of $\mathrm{R}^{2}$ for Langmuir isotherm model for limestone and laterite soil were 0.993 and 1 , respectively. These values demonstrated a very good mathematical fit of the experimental data since it were higher than 0.96 (Rout et al., 2014). The maximum adsorption capacities of E.coli, $Q$ can be determined from the obtained equation in the figures. Therefore, the obtained maximum adsorption capacities for limestone and laterite soil are $2500 \mathrm{MPN} / \mathrm{g}$ and 3333.3 MPN/g, respectively. The result demonstrates that laterite soil has higher adsorption capacities as compared with limestone. Since the media size used for laterite soil is smaller than limestone, therefore, it enhanced the higher capacities of E.coli to adsorb to the adsorbent due to the larger surface area as compared with larger particles of limestone (Fontes et al., 1991; Tan et al., 1992). Based on the obtained Langmuir isotherm equation, the calculated values of $R_{L}$ for limestone and laterite soil are -0.0002 and -0.000001 , respectively. The values of $R_{L}$ for both adsorbents were too small and nearly zero. The irreversible reaction might occur in the process. Bacterial adsorption and attachment to the surface of adsorbent is a two-step process. The first step is reversible adsorption. It takes place when the bacteria located in the secondary minimum overcome the secondary repulsive force between the bacteria and the porous material (Van Loosdrecht et al., 1990). In this phase, the primary forces involved were electrostatic force and van der waals force (Mozes et al., 1987). It is a reaction when the attached bacteria detached from the surface of the adsorbent particle and return the water phase. The second step is irreversible adsorption, which also referred to as adhesion. The reaction occur when bacterial polymers from bridges that connect the bacteria to the adsorbents (Stevik et al., 2004).

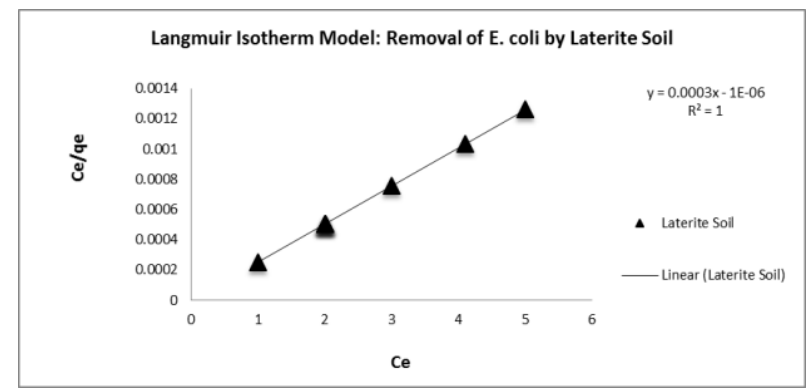

Figure 8. Langmuir Isotherm Model for removal of E.coli by laterite soil

\subsubsection{Freundlich Isotherm Model}

On the other hands, Freundlich isotherm model assumes the uptake of adsorbate occurs on a heterogeneous surface by multilayer adsorption and the amount of adsorbate adsorbed increases infinitely with an increase in concentration (Tchobanoglous, 2003; Halim et al., 2010). The Freundlich isotherm can be expressed as shown in
Equation (6) (Halim et al., 2010; Ismail et al., 2013; Rout et al., 2014):

$$
\mathrm{q}_{\mathrm{e}}=\mathrm{K}_{\mathrm{F}} \mathrm{C}_{\mathrm{e}}{ }^{1 / \mathrm{n}}
$$

Where;

$\mathrm{K}_{\mathrm{F}}=$ indicator of the adsorption capacity

$1 / n=$ adsorption intensity

The value of $K_{F}$ and $1 / n$ can be determined by plotting the graph in linear form of the Freundlich expression as shown in Equation (7), which $K_{f}$ can be determined from the intercept of the graph while $1 / n$ can be determined by the slope of the graph.

$$
\log q_{e}=\log K_{F}+\frac{1}{n} \log C_{e}
$$

In this study, the obtained correlation coefficient, $\mathrm{R}^{2}$ and linearized Freundlich isotherm equation for limestone and laterite soil were showed in Fig. 9 and Fig. 10.

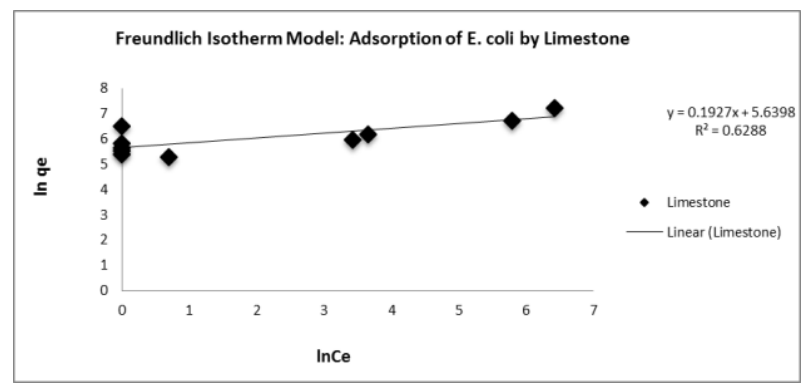

Figure 9. Freundlich Isotherm for Removals of E.coli by Limestone

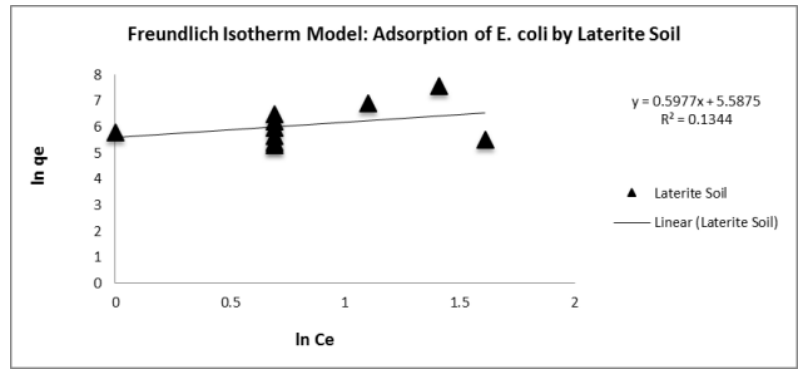

Figure 10. Freundlich Isotherm Model for removal of E.coli by laterite soil

Based on the figures, the values of $R^{2}$ for limestone and laterite soil were 0.62 and 0.18 , respectively. The $R^{2}$ values of this model for both adsorbents were lower than $R^{2}$ of Langmuir isotherm model. Besides that, the poor correlation coefficient for both materials has confirmed that the removal of E.coli does not fit to Freundlich isotherm model (Rout et al., 2014). However, the obtained values of $\mathrm{n}$ for limestone and laterite soil were 5.1894 and 1.673 , respectively. The $n$ values indicate whether the heterogeneous adsorption process were favorable if $n>1$, and unfavorable if $\mathrm{n}<1$ (Halim et al., 2010; Rout et al., 2014). 


\section{Conclusion}

The photocatalytic treatment of synthetic rainwater using $\mathrm{TiO}_{2}$ was studied to eliminate linden in this study. The results indicate that this advanced oxidation process was able to degrade lindane successfully with different experimental conditions such as $\mathrm{pH}, \mathrm{TiO}_{2}$ dosage, and initial concentration. The photodegradation process of lindane followed pseudo kinetic first order. The correlation coefficient of lindane is $\mathbf{0 . 5 8 5}$. Further studies need to be done in order to monitor the behavior and performance of lindane under a wider range of different experimental conditions.

The optimum adsorbent dosage of limestone and laterite soil in order to remove E.coli from synthetic rainwater is determined. The removal of E.coli was influenced by the size and chemical composition of media. Isotherm model were developed in order to determine the mechanism of adsorption in this study. Based on the obtained result, Langmuir isotherm model was the best fit model as compared with Freundlich isotherm model. It is because the correlation coefficients of Langmuir isotherm model for both materials were higher than Freundlich isotherm model. The equilibrium parameter of Langmuir isotherm, $\mathrm{R}_{\mathrm{L}}$ indicated small negative values for both materials. Since it is nearly zero, it can be concluded that the nature of the adsorption process was irreversible reaction. Therefore, it can be concluded that limestone and laterite soil are a potential media to remove E.coli from synthetic rainwater.

Overall, the processes of photocatalysis and adsorption showed a good performance in removing lindane and E.coli from the synthetic rainwater respectively. Based on the results, there is a potential to develop an integrated process by combining these two methods as a new treatment in the future. To date, there were also studies that have been done previously, that have utilized photocatalysis to remove E.coli while adsorption to remove lindane. Therefore, the idea of developing this integration method can be a good opportunity towards creating an efficient and advantageous method for removing biological and chemical contaminants present in the environment.

\section{Acknowledgement}

The authors would like to acknowledge Universiti Sains Malaysia (USM) for providing the fund for this study under grant RU (i); 1001/PAWAM/814193, MyBrain15 and also Centre of Drug Research, USM Main Campus, for providing the laboratory testing and facilities.

\section{References}

Al-Rasheed R.A. (2005). Water treatment by heterogeneous photocatalysis an overview. 4th SWCC acquired Experience Symposium held in Jeddah.

Amin M.T. and Han M.Y. (2011), Improvement of solar based rainwater disinfection by using lemon and vinegar as catalysts, Desalination, 276(1-3), 416-424.

Aziz H.A., Adlan M.N. and Ariffin K.S. (2008), Heavy metals (Cd, Pb, $\mathrm{Zn}, \mathrm{Ni}, \mathrm{Cu}$ and $\mathrm{Cr}(\mathrm{III}))$ removal from water in Malaysia: Post treatment by high quality limestone, Bioresource Technology, 99(6), 1578-1583.
Aziz H.A., Yusoff M.S., Adlan M.N., Adnan N.H. and Alias S. (2004), Physico-chemical removal of iron from semi-aerobic landfill leachate by limestone filter, Waste Management, 24(4), 353-358.

Basheer C., Balasubramanian R. and Lee H.K. (2003), Determination of organic micropollutants in rainwater using hollow fiber membrane/liquid-phase microextraction combined with gas chromatography-mass spectrometry, Journal of Chromatography A, 1016(1), 11-20.

Bosco M., Callao M. and Larrechi M. (2006), Simultaneous analysis of the photocatalytic degradation of polycyclic aromatic hydrocarbons using three-dimensional excitation-emission matrix fluorescence and parallel factor analysis, Analytica chimica acta, 576(2), 184-191.

Chong M.N., Jin B., Chow C.W.K. and Saint C. (2010), Recent developments in photocatalytic water treatment technology: a review, Water Research, 44(10), 2997-3027.

Devipriya S. and Yesodharan S. (2005), Photocatalytic degradation of pesticide contaminants in water, Solar Energy Materials and Solar Cells, 86(3), 309-348.

Esplugas S., Gimenez J., Contreras S., Pascual E. and Rodriguez M. (2002), Comparison of different advanced oxidation processes for phenol degradation, Water Research, 36(4), 1034-1042.

Fontes D.E., Mills A.L., Hornberger G.M. and Herman J.S. (1991), Physical and chemical factors influencing transport of microorganisms through porous media, Applied and Environmental Microbiology, 57(9), 2473-2481.

Fuping, W., L. Xu, T. Zhenzhen and Xiaofei Y. (2012), Research on cellar rainwater of northwest region villages and small towns enhanced coagulation by potassium permanganate combined with powdered activated carbon, Geomatics for Integrated Water Resources Management (GIWRM), 2012 International Symposium on.

Gan L., Zuo J., Xie B., Li P. and Huang X. (2012), Zeolite (Na) modified by nano-Fe particles adsorbing phosphate in rainwater runoff, Journal of Environmental Sciences, 24(11), 1929-1933.

Gaya U.I. and A.H. Abdullah (2008), Heterogeneous photocatalytic degradation of organic contaminants over titanium dioxide: a review of fundamentals, progress and problems, Journal of Photochemistry and Photobiology C: Photochemistry Reviews, 9(1), 1-12.

Gikas G.D. and V.A. Tsihrintzis (2012), Assessment of Water Quality of First-Flush Roof Runoff and Harvested Rainwater, Journal of Hydrology, 466-467(0), 115-126.

Halim A.A., Hamidi A.A., Johari M.A.M. and Ariffin K.S. (2010), Comparison study of ammonia and COD adsorption on zeolite, activated carbon and composite materials in landfill leachate treatment, Desalination, 262(1-3), 31-35.

He J. and Balasubramanian R. (2009), A study of precipitation scavenging of semivolatile organic compounds in a tropical area, Journal of Geophysical Research, 114(D12).

He J. and Balasubramanian R. (2010), Semi-volatile organic compounds (SVOCS) in ambient air and rainwater in a tropical environment: concentrations and temporal and seasonal trends, Chemosphere, 78(6), 742-751.

Huang D., Peng P., Xu Y., Dengy Y. and Deng H. (2009), Distribution and deposition of polycyclic aromatic hydrocarbons in precipitation in Guangzhou, South China, Journal of Environmental Sciences, 21(5), 654-660. 
Huysman F. and Verstraete W. (1993), Effect of cell surface characteristics on the adhesion of bacteria to soil particles, Biology and fertility of soils, 16(1), 21-26.

Ismail M.G.B.H., Weng C.N., Rahman H.A. and Zakaria N.A. (2013), Freundlich Isotherm Equilibrium Equastions in Determining Effectiveness a Low Cost Absorbent to Heavy Metal Removal In Wastewater (Leachate) At Teluk Kitang Landfill, Pengkalan Chepa, Kelantan, Malaysia, Journal of Geography and Earth Science, 1(1), 1-8.

Jordan F.L., Seaman R., Riley J.J. and Yoklic M.R. (2008), Effective removal of microbial contamination from harvested rainwater using a simple point of use filtration and UVdisinfection device, Urban Water Journal, 5(3), 209-218.

Konstantinou I.K. and Albanis T.A. (2004), $\mathrm{TiO}_{2}$-assisted photocatalytic degradation of azo dyes in aqueous solution: kinetic and mechanistic investigations, Applied Catalysis B: Environmental, 49(1), 1-14.

Lair A., Ferronato C., Chovelon J.-M. and Herrmann J.-M. (2008), Naphthalene degradation in water by heterogeneous photocatalysis: an investigation of the influence of inorganic anions, Journal of photochemistry and photobiology A: chemistry, 193(2), 193-203.

Lau Y.-Y., Wong Y.-S., Teng T.-T., Morad N., Rafatullah M. and Ong S.-A. (2014), Coagulation-flocculation of azo dye Acid Orange 7 with green refined laterite soil, Chemical Engineering Journal, 246(0), 383-390.

Li Y.T., Li F.B., Chen J.J., Yang G.Y., Wan H.F., Zhang T.B., Zeng X.D. and Liu J.M. (2008), The concentrations, distribution and sources of PAHs in agricultural soils and vegetables from Shunde, Guangdong, China, Environmental monitoring and assessment, 139(1-3), 61-76.

Mahmoodi V. and Sargolzaei J. (2014), Optimization of photocatalytic degradation of naphthalene using nano$\mathrm{TiO}_{2} / \mathrm{UV}$ system: statistical analysis by a response surface methodology, Desalination and Water Treatment, 52(34-36), 6664-6672.

Mahugija J.A., Henkelmann B. and Schramm K.W. (2015), Levels and patterns of organochlorine pesticides and their degradation products in rainwater in Kibaha Coast Region, Tanzania, Chemosphere, 118, 12-19.

Maiti A., Thakur B.K., Basu J.K. and De S. (2013), Comparison of treated laterite as arsenic adsorbent from different locations and performance of best filter under field conditions, Journal of Hazardous Materials, 262(0), 1176-1186.

Malato S., Fernández-Ibáñez P., Maldonado M.I., Blanco J. and Gerjak W. (2009), Decontamination and disinfection of water by solar photocatalysis: Recent overview and trends, Catalysis Today, 147(1), 1-59.

Mozes N., Marchal F., M. Hermesse M.P., Van Haecht J.L., Reuliaux L., Leonard A.J. and Rouxhet P.G. (1987), Immobilization of microorganisms by adhesion: interplay of electrostatic and nonelectrostatic interactions, Biotechnology and Bioengineering, 30(3), 439-450.

Muneer M., Qamar M., Saquib M. and Bahnemann D.W. (2005), Heterogeneous photocatalysed reaction of three selected pesticide derivatives, propham, propachlor and tebuthiuron in aqueous suspensions of titanium dioxide, Chemosphere, 61(4), 457-468.

Naddeo V., Scannapieco D. and Belgiorno V. (2013), Enhanced drinking water supply through harvested rainwater treatment, Journal of Hydrology, 498(0), 287-291.
Pang, W.-H., Gao N.-Y., Deng Y. and Tang Y.-L. (2009), Novel photocatalytic reactor for degradation of DDT in water and its optimization model, Journal of Zhejiang University SCIENCE A, 10(5), 732-738.

Rianawati E. and Balasubramanian R. (2009), Optimization and validation of solid phase micro-extraction (SPME) method for analysis of polycyclic aromatic hydrocarbons in rainwater and stormwater, Physics and Chemistry of the Earth, Parts $A / B / C$, 34(13-16), 857-865.

Robertson P.K., Robertson J.M. and Bahnemann D.W. (2012), Removal of microorganisms and their chemical metabolites from water using semiconductor photocatalysis, Journal of Hazardous Materials, 211-212, 161-171.

Rout P.R., Bhunia P. and Dash R.R. (2014), A mechanistic approach to evaluate the effectiveness of red soil as a natural adsorbent for phosphate removal from wastewater, Desalination and Water Treatment, 54(2), 358-373.

Silva A.M., Cunha E.C., Silva F.D.R. and Leao V.A. (2012), Treatment of high-manganese mine water with limestone and sodium carbonate, Journal of Cleaner Production, 29-30(0), 11-19.

Stevik T.K., Aa K., Ausland G. and Hanssen J.F. (2004), Retention and removal of pathogenic bacteria in wastewater percolating through porous media: a review, Water Research, 38(6), 1355-1367.

Tan Y., Bond W.J. and Griffin D. (1992), Transport of bacteria during unsteady unsaturated soil water flow, Soil Science Society of America Journal, 56(5), 1331-1340.

Tchobanoglous G.B., Franklin L., Stensel, H David. (2003), Wastewater engineering: treatment and reuse. New York. , McGraw-Hill.

Van Loosdrecht M.C., Lyklema J., Norde W. and Zehnder A.J. (1990), Influence of interfaces on microbial activity, Microbiological reviews, 54(1), 75-87.

Wang H., Gui H., Yang W., Li D., Tan W., Yang M. and Barrow C.J. (2013), Ammonia nitrogen removal from aqueous solution using functionalized zeolite columns, Desalination and Water Treatment, 52(4-6), 753-758.

Wang Y., Sikora S. and Townsend T.G. (2013), Ferrous iron removal by limestone and crushed concrete in dynamic flow columns, Journal of Environmental Management, 124, 165-171.

Wilbers G.-J., Sebesvari Z., Rechenburg A. and Renaud F.G. (2013), Effects of local and spatial conditions on the quality of harvested rainwater in the Mekong Delta, Vietnam, Environmental Pollution, 182(0), 225-232.

Yang G., Ma L., Xu D., Liu L., Jia H., Chen Y., Zhang Y. and Chai Z. (2012), Temporal variations of organochlorine pesticides in precipitation in Beijing, China, Atmospheric Environment, 61, 614-619.

Yang Y., Zhang G., Yang H. and Dang R. (2015), Study on Cellar Rainwater Treated by different size BAC in Villages and Towns of Northwestern China. 2015 Asia-Pacific Energy Equipment Engineering Research Conference, Atlantis Press.

Zaleska A., Hupka J., Wiergowski M. and Biziuk M. (2000), Photocatalytic degradation of lindane, $p, p^{\prime}$-DDT and methoxychlor in an aqueous environment, Journal of photochemistry and photobiology A: Chemistry, 135(2), 213220. 